\title{
Reviewer Acknowledgements for Global Journal of Health Science, Vol. 14, No. 3
}

Global Journal of Health Science wishes to acknowledge the following individuals for their assistance with peer review of manuscripts for this issue. Their help and contributions in maintaining the quality of the journal are greatly appreciated.

Global Journal of Health Science is recruiting reviewers for the journal. If you are interested in becoming a reviewer, we welcome you to join us. Please contact us for the application form at: gjhs@ccsenet.org.

\section{Reviewers for Volume 14, Number 3}

Ama Pokuaa Fenny, University of Ghana, Ghana

Ayesha Johnson, University of South Florida, United States of America

Farahnaz Amini, UCSI University, Malaysia

Gavric Zivana, University Banja Luka, Bosnia and Herzegovina

Georgann Valerie Weissman, Capella University, United States of America

Kartheek R Balapala, University Tunku Abdul Rahman, Malaysia

Krzysztof Goniewicz, Medical University of Warsaw, Poland

Loray Daws, British Columbia Masterson Institute, Canada

Marcel Wullschleger, University of Bern, Switzerland

Meng Zhao, Texas A\&M University at Corpus Christi, United States of America

Pedram Iranmanesh, Dentist, Independent Researcher, Iran

Pi-Ming Yeh, Missouri Western State University, United States of America

Samir Othman, Hawler Medical University, Iraq

Soontareeporn Meepring, Naresuan University, Thailand

Tawheda El-saidy, Menoufia University, Egypt

Thandiwe Marethabile Letsie, University of the Free State, South Africa

Thanusin Saleeon, Mae Fah Lung University, Thailand 